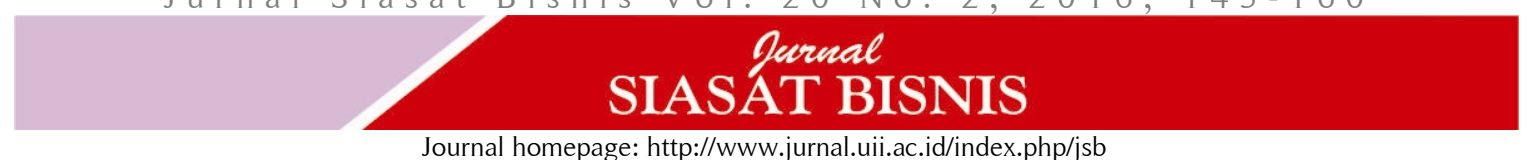

\title{
Factors Affecting The Use of E-Commerce In Creative Industries: Empirical Evidences From SMEs In Jabodetabek-Indonesia
}

\author{
Donny Oktavian Syah ${ }^{* 11}$, Rambat Lupiyoadi ${ }^{2}$, Adi Pramudita Tjiptadi ${ }^{3}$ \\ ${ }^{1}$ Department of Business Administration, \\ LP3I Polytechnics Jakarta, Indonesia \\ *Correspondence author e-mail: donny@plj.ac.id \\ ${ }^{2,3}$ Department of Management \\ University of Indonesia, Depok-Indonesia \\ e-mail: rambat.lupiyoady@ui.ac.id \\ e-mail: pramudita.tjiptadi@gmail.com
}

\begin{abstract}
The goal of this research is to identify factors that influences; organizational readiness, external pressure, perceived ease of use, and perceived benefit that can be obtained from adoption of e-commerce in SMEs creative industries in Jabodetabek city (Jakarta, Bogor, Depok, Tangerang and Bekasi). Our analysis demonstrates that there is a relationship between organizational readiness, and perceived benefits variables to e-commerce adoption of SMEs creative industries in Jabodetabek, Indonesia. On the other hand, variable of the external pressure and the perceived ease of use (complexity) did not significantly influence the e-commerce adoption in SMEs creative industries in Jabodetabek.
\end{abstract}

Keywords: creative industries, e-Commerce adoption, small \& medium enterprises (SMEs), SMEs of Jabodetabek-Indonesia

\begin{abstract}
Abstrak
Tujuan dari penelitian adalah untuk mengindentifikasi faktor faktor yang mempengaruhi kesiapan organisasi (organizational readiness), tekanan dari pihak eksternal (external pressure), kemudahan penggunaan (perceived ease of use) dan faktor manfaat implementasi e-commerce (perceived benefit) terhadap adopsi pemakaian transaksi online (e-commerce adoption) di lingkungan UKM Industri Kreatif yang berlokasi di Jabodetabek (Jakarta, Bogor, Depok, Tangerang, and Bekasi). Hasil riset menunjukkan bahwa ada korelasi signifikan antara kesiapan organisasi (organizational Readiness), dan faktor manfaat implementasi e-commerce (perceived of bendefit) dengan implementasi pemakaian transaksi on-line (e-commerce adoption) di lingkungan UKM industri kreatif di area Jabodetabek, Indonesia. Sebaliknya, variabel tekanan dari pihak eksternal (external pressure) dan kemudahan penggunaan (perceived ease of use) tidak mempunyai pengaruh yang signifikan terhadap adopsi pemakaian transaksi on-line (e-commerce adoption).
\end{abstract}

Kata kunci: Adopsi transaksi on-line (e-commerce), Industri Kreatif, Usaha Kecil dan Menengah (UKM), UKM Jabodetabek-Indonesia

JEL: L80, L81, M15, M31

DOI: 10.20885/jsb.vol20.iss2.art4

\section{Introduction}

SMEs (Small and Medium Enterprises) play a very vital role in Indonesia, especially as a source of employment and its contribution to national GDP. In the year 2010, SMEs employed more than 95 million people, an increase of 9 million since 2006. Meanwhile, the same number for large enterprises were only 500,000 workers. Similarly, in terms of GDP contribution, SMEs contributed with Rp. 3,400 Trillion, while large enterprises Rp 2,600 trillion in the same year (Ministry of Cooperative and Small Medium Enterprise, 2012). However, it must be noted that large enterprises only 
consist of $0.01 \%$ of the total existing business units. In order to further strengthen and develop the strong position that SMEs possess in Indonesia, as based on the description above, SMEs need increasing support.

In the era of globalization and information, one of the things that can be done is adopting the use of e-commerce. Jacobs and Downsland (2000) revealed that the e-commerce made SMEs able to compete and gain competitive advantage. Grandon and Pearson (2004) defined e-commerce as the process of buying and selling of products or services by electronic media through the Internet. The use of e-commerce also increased productivity by 10\% (Waizly, 2012). Nevertheless, there are still only few Indonesian SMEs that utilizes e-commerce for business purposes. Based on Statistics Bureau of Indonesia (BPS) data, there have been 75,000 new SMEs in Indonesia, of the total of tens of millions existing SMEs, which have been using e-commerce (Waizly, 2012). In fact, with the implementation of e-commerce, there is a potential increase in revenue of Rp. 330 trillion (Kontan.co.id, 2012).

Among various types of SMEs, those operating in creative industries are considered as the most relevant to adopt information technology such as e-commerce. This group of SMEs continue to grow; until 2008, the SME creative industries have increased by 5.67\% equivalent to Rp. 104.8 Trillion (Ministry of Trade of Republic Indonesia, 2009). How do the SME creative industries adopt e-commerce? What are the factors that influence the use of e-commerce in SMEs, especially the SME creative industries? Several previous studies have revealed multiple factors influencing the use of e-commerce in SMEs factors such as organizational readiness, external pressure, perceived ease of use (complexity) and perceived benefits of e-commerce itself.

Based on data from Ministry of Trade (Indonesia), there are 14 sectors that make up the pillars of creative industry; including publication and printing, design and architecture, arts and antique market, craft and art industry, designing, fashion, video-film-photography, interactive gaming, music, performance art, publishing and printing, software and computer services, television and radio, research and development. In this study, the research focus on SMEs which operate in 14 sectors above in Jabodetabek area.

\section{Literature Review}

This study attempts to answer the question on whether or not those factors mentioned above, namely the organizational readiness, external pressure, perceived of ease of use, and perceived benefits of using e-commerce, in the developing countries like Indonesia, have significant effects on ecommerce adoption for creative SMEs in Jabodetabek.

\section{Organizational readiness}

Organizational readiness or the level of preparation of the organization, can be identified by several factors such as the availability of the internet, the characteristics of the SME itself, the ability to use devices like computer and other electronic devices in accordance with the use of e-commerce by employees or managers of SMEs, as well as the availability of staff to handle any jobs related to the use of e-commerce itself. Chong et al. (2001) in Shaharudin et al. (2012) explains that the organization has been ready to adopt e-commerce, meaning that all devices and tools have been prepared. Moreover, support from the owner or top management is an important factor to find out whether or not the organization has been able to adopt e-commerce.

Another important aspect about the readiness of the organization is as Mehrtens et al. (2001) pointed out, the ability to use IT for non-IT professionals. In other words, IT skills must be possessed by all managers even though they are not experts in the IT field. In addition, Mehrtens (2001) also use the term organizational readiness, it means the ability to use IT infrastructure in supporting other business aspects in SMEs, for instance the supply of computer hardware, access to the internet, in order to support the implementation of e-commerce. 
Beatty et al. explain that the organizational readiness can also mean the technology-related infrastructure which must be present in order to facilitate new innovations that will emerge in the future. Organizational readiness, as described by Shaharudin et al. (2011) is the availability of funds for the various needs to adopt, and other supporting infrastructure to utilize e-commerce.

Based on the discussion above, we therefore propose the following hypothesis: H1 organizational readiness affect e-commerce adoption.

\section{External pressure}

The use of e-commerce in SMEs is also influenced by organizational external factors. Mehrtens et al. (2001) explain that organizational external factors originate from pressure of other internet users, especially suppliers and consumers who mainly communicate electronically. Besides, Grandon and Pearson (2004) reveal that SMEs are also affected by the pressure of their surrounding environment. This is because SMEs basically depend on the consumers in order to be able to survive in the industry. They suggest that creating relationships with suppliers through electronic media can reduce operational costs and the organizations themselves become more competitive in the market.

Dholakia et al. (2004) reveal that the competitive business environment also gives a strong influence in the adoption of technology. Another statement, also suggested by Chong, et al. (2009) said that the decision to adopt e-commerce is also influenced by the pressure of competition and the presence of competitors who have used the e-commerce previously.

As external enforcement is one consideration factor to adopt e-commerce, we therefore propose the following hypothesis: H2: External pressure affect e-commerce adoption.

\section{Perceived ease of use (complexity)}

Perceived ease of use factor is user perception of complex situation when implementing ecommerce in their institutions. The term of perceived ease of use is a factor commonly used interchangebly with complexity. Beatty, et al. (2001) explain that the complexity is a measure of the difficulty in exploring and understanding an innovation. While Rogers (2003) describes complexity as any problems to understand and learn to apply an innovation. Employees need to develop their capabilities to use new technology. This situation is not easy as the employees have been accustomed to their habits. Hence, the employees tend to avoid learning new skills.

Another study conducted by Grandon and Pearson (2004) reveal that the ease in using technology is an important factor in the adoption of e-commerce in SMEs. Because they must prepare and set-up their employees to be ready to study e-commerce. The challenge is, most employees will be reluctant to study a new skill if they think that using internet and e-commerce are too complicated, especially the older employees. Moreover, not all SMEs have the budget to train their employees.

So, as one important factor in adoption of e-commerce, we put forward the following hypothesis : H3: Perceived ease of use (complexity) affect e-commerce adoption.

\section{Perceived of benefits}

Mehrtens, et al. (2001) found that the benefits from using e-commerce is identified by the relative advantages in using the internet compared to traditional methods, such as telephone, fax and post, when communicating with consumers and others. They also pointed out that the benefit in using ecommerce can also mean saving some expenses. In addition, by applying e-commerce, the organization can find information about competitors, government regulations, products, and stocks owned by the supplier, which is another benefit of e-commerce.

Kuan and Chau (2001) describes levels of benefit that can be obtained from the use of the technology to the organization or business. They classify benefits into direct benefits and indirect benefits. The direct benefit is a benefit that is related to the efficiency in costs. Meanwhile, indirect 
benefits refer to anything that affect the business processes, business relationships like the image of the organization, the attempt in increasing competitiveness, the improvement in customer service and in maintaining relationships with business relations.

Based on studies conducted by Beatty, et al. (2001), it can be inferred that the use and adoption of web-based technology is basically influenced by the benefits that can be obtained by the organizations, such as having lower transaction costs, improving cash flow, increasing productivity, improving customer service, having more competitive environment, having greater opportunity to get more new customers, building better relationships with customers, and increasing operational efficiency.

Given the preceding discussion, the following hypothesis is proposed: H4: Perceived of benefit affect e-commerce adoption.

\section{E-commerce adoption}

E-commerce adoption can be implemented in all aspects and in all kinds of SMEs. The scope of internet usage in business of SMEs is very wide, ranging from simple information to full electronic transaction. The Internet is applicable in the process of production, distribution or marketing and sales, and or delivery of goods and services. According to Kalkota and Whinston (1997), it is said that e-commerce can be adopted in all activities of providing information on products and services from SMEs. Also, the use of e-commerce in SMEs can also mean giving service to consumers via the Internet and conducting the process of trading products to the international market (Lawson et al, 2003). In this study, E-commerce adoption is a dependent variable.

In order to make this research easier to understand, our theoretical framework is designed in Figure 1 as follows:

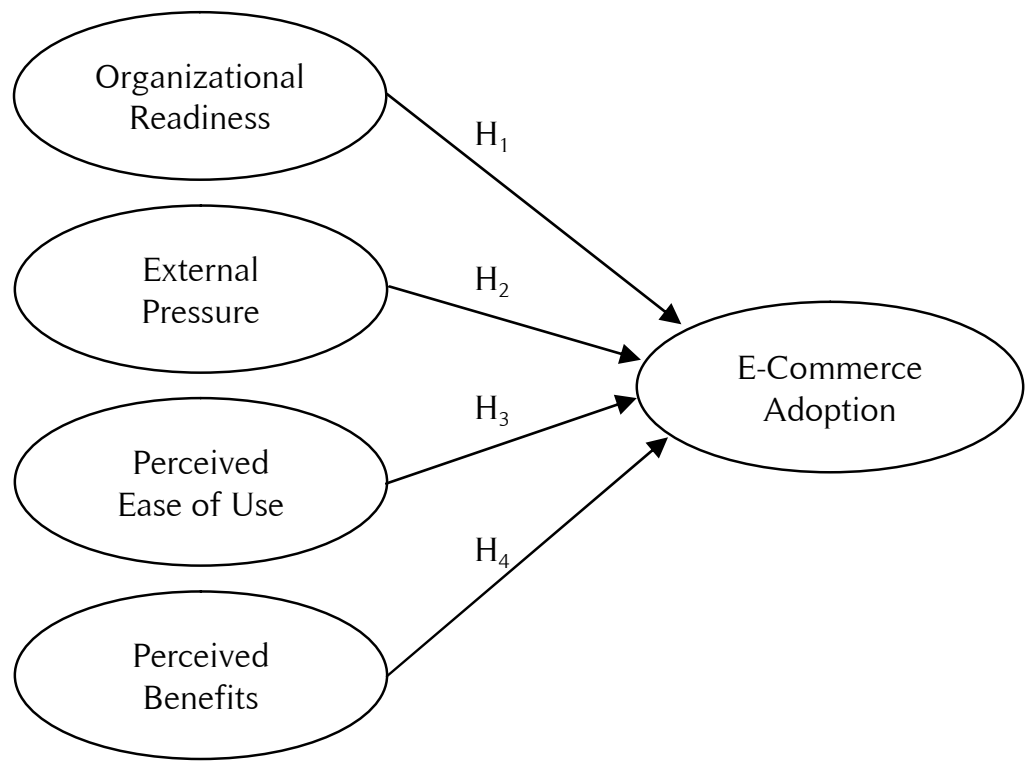

Figure 1. Theoretical Framework

The theoretical framework above has ever been conducted by Shaharudin et al. (2012) to examine the determinant of e-commerce adoption in Malaysian SMEs case that their core business on furniture industry. Based on their research, the authors predict that all four variables above (organizational readiness, external pressure, perceived ease of use and perceived benefits) have also affected to e-commerce adoption in creative industries in Jabodetabek, Indonesia. 


\section{Hypothesis}

Given the preceding discussion in theoretical above, the following hypotheses are proposed:

$\mathrm{H} 1$ : There is significant relationship between organizational readiness and adoption e-commerce.

$\mathrm{H} 2$ : There is significant relationship between external pressure and adoption e-commerce.

H3: There is significant relationship between perceived ease of use and adoption e-commerce.

$\mathrm{H} 4$ : There is significant relationship between perceived benefit of and adoption e-commerce

\section{Research Methods}

\section{Research design}

In this study the authors applied a quantitative approach. The population in this study was taken from SMEs creative industries in Jabodetabek (Jakarta, Bogor, Depok, Tangerang, Bekasi city) that have been applying e-commerce. Data collection conducted by distributing questionnaires to the respondents directly via e-mail (private message). The sampling technique is non-probability sampling, especially judgmental non-probability sampling, Cooper and Schindler (2006), in which the authors conducted pre-research in the samples chosen to find out the accordance with the criteria of the study population.

The questionnaire consists of screening question, statements using Likert scale with six points and multiple choice questions to find out characteristics and the profile of the respondents.

In this study, 75 responses were received from 150 questionnaires. Based on Hussey and Hussey (1997), for mail distribution method, to avoid sample bias, response rate should be more than $10 \%$. In this study, the response is $50 \%$. It means that sample bias was avoided.

The validity of the measurement tested in the pre-test by using the Pearson Correlation method. Meanwhile, the reliability is judged by using Cronbach alpha formula and classic assumption test. The analysis is conducted by using the multiple regression method. The multiple regression method is conducted to see the effect of each independent variable on the dependent variable. The result of the research was examined by statistical software for social science (SPSS) version 17.0.

\section{Respondent data}

This sub topic of respondents explains several categories related to respondents. They are Respondents' Business Sub-Category, Respondents' Standing Period of Business, Respondents' Employees Number, and Respondents' e-commerce level of use as shown respectively in Figure 2 until Figure 5.

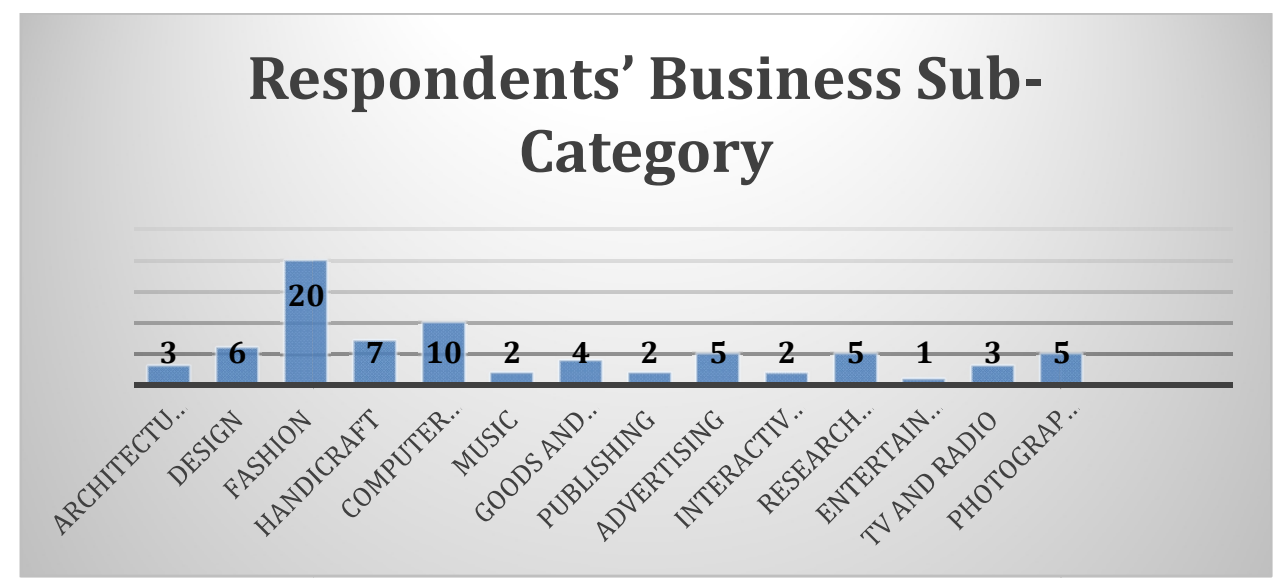

Source: Author's Data

Figure 2. Respondents' Business Sub-Category 


\section{Respondents' Standing Period of Business}

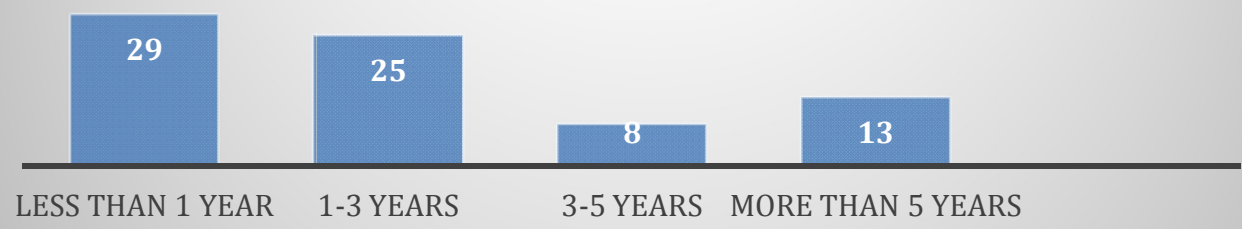

Source: Authors's Data

Figure 3. Respondents' Standing Period of Business

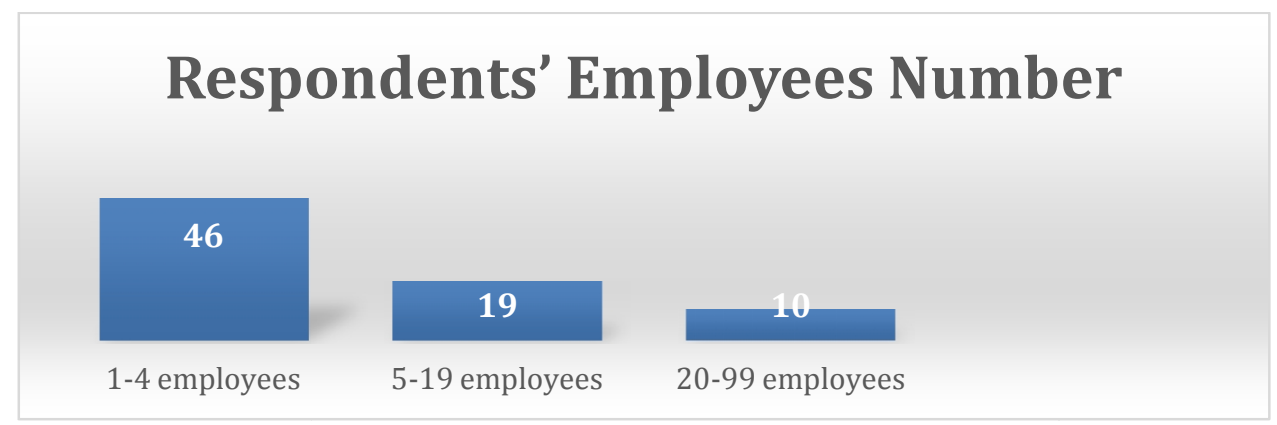

Source: Authors's Data

Figure 4. Respondents' Employees Number

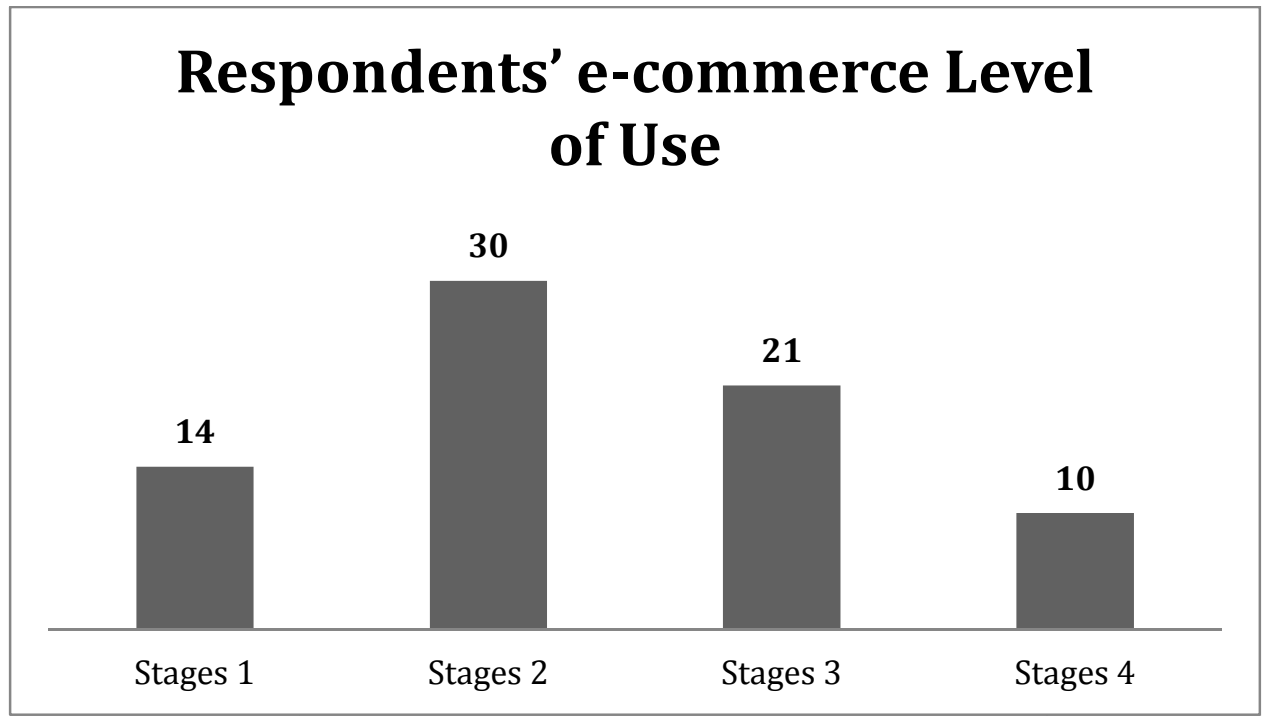

Source:Author's Data

Figure 5. Respondents' e-commerce Level of Use 
Level of e-commerce use in figure 5 is using e-commerce activities based on Chen and McQueen (2008). Based on the data above, mostly SMEs creative industries in Jabodetabek e-commerce activities are in stage 2 and 3 . There are 5 stages of e-commerce:

\begin{tabular}{|c|c|}
\hline Stages & E-commerce Activities \\
\hline Stage 1 (Messaging) & $\begin{array}{l}\text { 1. Searching information. } \\
\text { 2. Using online service } \\
\text { 3. Using E-mail to communicate with customers and suppliers. }\end{array}$ \\
\hline $\begin{array}{l}\text { Stage } 2 \\
\text { (Online Marketing) }\end{array}$ & $\begin{array}{l}\text { 1. Having a static website and online version of paper-based catalogue. } \\
\text { 2. Extensive using e-mail to communicate and exchanging document } \\
\text { with customers, suppliers, and employees. } \\
\text { 3. E-mail ordering. }\end{array}$ \\
\hline $\begin{array}{l}\text { Stege } 3 \\
\text { (Online Ordering) }\end{array}$ & $\begin{array}{l}\text { 1. Having two-ways information interactive website that provide topic } \\
\text { searches and company information queries. } \\
\text { 2. Using shopping-cart software to place order on website. } \\
\text { 3. Fulfilling payment manually by bank deposit, bank che commercek or } \\
\text { internet banking. } \\
\text { 4. Expanding the potential market internationally. }\end{array}$ \\
\hline $\begin{array}{l}\text { Stage } 4 \text { (Online } \\
\text { Transaction) }\end{array}$ & $\begin{array}{l}\text { 1. Online order fulfilment can be accomplished automatically, that is an } \\
\text { order can be commerceived or confirmed, and an invoice can be } \\
\text { issued or re-commerceived on-line. } \\
\text { 2. Online payment can be undertaken through debit and credit cards, ele- } \\
\text { commercentronic cash, ele-commercentronic fund transfer, or through } \\
\text { an EDI service. } \\
\text { 3. Integrating online front-end and back-end system. } \\
\text { 4. Expanding the potential market internationally. }\end{array}$ \\
\hline Stage 5 (E-business) & $\begin{array}{l}\text { grating all these activities with the internal processing of a business } \\
\text { ugh ICT. }\end{array}$ \\
\hline
\end{tabular}

Source: Chen \& McQueen (2008)

Figure 6. E-commerce Activities Stage

\section{Result and Discussion}

Result

Pre-test questionnaire conducted to 30 sample respondents. The reliability of each research variable is identified by the value of Cronbach Alpha in each dimension. The test result shows the score of the reliability for all statements of each variable in the questionnaire is above 0.70 . This score means that all the statements in the questionnaire are reliable to describe the variables in this study as displayed in Table 1.

Table 1. Results on Reliability Test by Cronbach Alpha

\begin{tabular}{lc}
\hline Variables & Alpha Cronbach \\
\hline Organizational Readiness & 0.81 \\
External Pressure & 0.78 \\
Perceived ease of Use & 0.84 \\
Perceived Benefits & 0.82 \\
E-commerce Adoption & 0.72 \\
\hline
\end{tabular}

Source: Result of Data Processing using SPSS 17.0

Meanwhile, the validity test by Pearson Correlation validity test showed that all dimensions of each variable are valid as shown in Table 2. 
Table 2. Pearson Correlation Validity Test Result

\begin{tabular}{|c|c|c|c|}
\hline Dimensions & R Score & R Table & Results \\
\hline OR1 & 0.66 & 0.36 & Valid \\
\hline OR2 & 0.42 & 0.36 & Valid \\
\hline OR3 & 0.59 & 0.36 & Valid \\
\hline OR4 & 0.45 & 0.36 & Valid \\
\hline OR5 & 0.55 & 0.36 & Valid \\
\hline OR6 & 0.37 & 0.36 & Valid \\
\hline OR7 & 0.37 & 0.36 & Valid \\
\hline OR8 & 0.71 & 0.36 & Valid \\
\hline OR9 & 0.59 & 0.36 & Valid \\
\hline OR10 & 0.58 & 0.36 & Valid \\
\hline OR11 & 0.71 & 0.36 & Valid \\
\hline OR12 & 0.73 & 0.36 & Valid \\
\hline OR13 & 0.48 & 0.36 & Valid \\
\hline EP1 & 0.63 & 0.36 & Valid \\
\hline EP2 & 0.61 & 0.36 & Valid \\
\hline EP3 & 0.45 & 0.36 & Valid \\
\hline EP4 & 0.79 & 0.36 & Valid \\
\hline EP5 & 0.88 & 0.36 & Valid \\
\hline EP6 & 0.62 & 0.36 & Valid \\
\hline EP7 & 0.63 & 0.36 & Valid \\
\hline CO1 & 0.76 & 0.36 & Valid \\
\hline $\mathrm{CO} 2$ & 0.70 & 0.36 & Valid \\
\hline $\mathrm{CO} 4$ & 0.81 & 0.36 & Valid \\
\hline $\mathrm{CO} 5$ & 0.77 & 0.36 & Valid \\
\hline $\mathrm{CO6}$ & 0.74 & 0.36 & Valid \\
\hline BE1 & 0.62 & 0.36 & Valid \\
\hline BE2 & 0.71 & 0.36 & Valid \\
\hline BE3 & 0.65 & 0.36 & Valid \\
\hline BE4 & 0.57 & 0.36 & Valid \\
\hline BE5 & 0.48 & 0.36 & Valid \\
\hline BE6 & 0.67 & 0.36 & Valid \\
\hline BE7 & 0.57 & 0.36 & Valid \\
\hline BE8 & 0.56 & 0.36 & Valid \\
\hline BE9 & 0.64 & 0.36 & Valid \\
\hline BE10 & 0.62 & 0.36 & Valid \\
\hline BE11 & 0.51 & 0.36 & Valid \\
\hline BE12 & 0.57 & 0.36 & Valid \\
\hline AE1 & 0.42 & 0.36 & Valid \\
\hline AE2 & 0.75 & 0.36 & Valid \\
\hline AE3 & 0.46 & 0.36 & Valid \\
\hline AE4 & 0.49 & 0.36 & Valid \\
\hline AE5 & 0.61 & 0.36 & Valid \\
\hline AE6 & 0.69 & 0.36 & Valid \\
\hline AE7 & 0.72 & .036 & Valid \\
\hline AE8 & 0.70 & 0.36 & Valid \\
\hline
\end{tabular}

\section{Classical Test Assumptions}

Classical Assumption Test shows that there are no any problems im Normality, autocorrelation, and multicolinearity Heterodesicty (see Figure 7). 
Normality test

\section{Histogram}

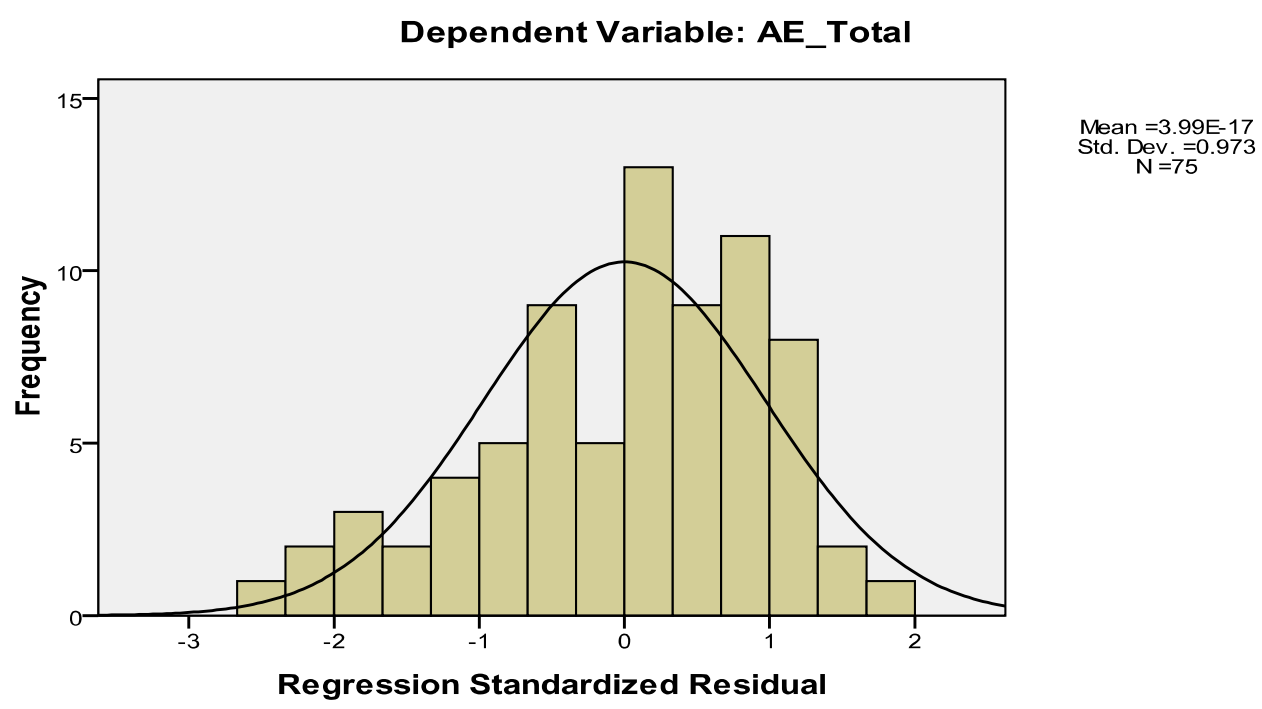

Source: Results of Data Processing using SPSS 17.0

Figure 7. Residual Histogram Test

Table 3. One Sample Kolmogorov-Smirnov - Residual

\begin{tabular}{ll}
\hline Mean & 0.00 \\
\hline Standard deviation & 3.89 \\
Kolmogorov-Smirnov test & 0.91 \\
\hline
\end{tabular}

Source: Results of Data Processing using SPSS 17.0

\section{Auto Correlation Test}

Table 4. Adjusted R-Square and Durbin-Watson Test

\begin{tabular}{ll}
\hline R-Square & 0.48 \\
\hline Adjusted R-Square & 0.45 \\
Durbin Watson & 1.88 \\
\hline
\end{tabular}

Source: Results of Data Processing using SPSS 17.0

The result of Durbin Watson test for auto correlation is 1.88 . This value shows that the correlation is still in the range of ( $d U$ of $\alpha=5 \%, n=72, k=4$ ) and 1.73 (4-dU) 1.7366) 2.26. Thus, this means that there were no any autocorrelation problem in these data variables as displayed in Table 4.

\section{Heteroscedasticity Test}

Table 5. Heteroscedasticity Test

\begin{tabular}{lc}
\hline Variable & Heteroscedasticity Test \\
\hline Organizational readiness & 0.72 \\
External pressure & 0.85 \\
Perceived ease of use & 0.41 \\
Perceived benefit & 0.99 \\
\hline
\end{tabular}

Source: Results of Data Processing Using SPSS 17.0 
For Heteroscedasticity test, the significant score for correlation is more than 0.05 . It means that the regression model has no heteroscendasticity problem as shown in Table 5.

\section{Multicollinearity Test}

Based on coefficient output-collinearity statistics, VIF (Variance Inflation Factor) value as obtained are between 1 to 10 . Therefore, it can be concluded that there are no multicollinearity symptoms between the independent variables in the regression model as displayed in Table 6.

Table 6. Multicollinearity Test

\begin{tabular}{lc}
\hline Variable & Variance Inflation Factor \\
\hline Organizational readiness & 1.34 \\
External pressure & 1.41 \\
Perceived ease of use & 1.17 \\
Perceived benefit & 1.36 \\
\hline
\end{tabular}

Source: Results of Data Processing Using SPSS 17.0

\section{Correlation Analysis}

Table 7. Correlation Test on Dependent and Independent Variables

\begin{tabular}{lc}
\hline Variable & Pearson Correlation \\
\hline Organizational readiness & 0.47 \\
External pressure & 0.42 \\
Perceived ease of use & 0.28 \\
Perceived benefit & 0.63 \\
\hline
\end{tabular}

Source: Results of Data Processing Using SPSS 17.0

The analysis shows that all the independent variables (organizational readiness, external pressure, perceived ease of use and perceived benefits that can be obtained from the use of e-commerce in SMEs creative industries) correlate positively to e-commerce adoption as shown in Table 7.

\section{Multiple Regression Analysis and Test R and R Square}

Table 8. R Square Test and Adjusted R Square

\begin{tabular}{lc}
\hline Test & Result \\
\hline R-Square & 0.48 \\
Adjusted R-Square & 0.45 \\
Standard Error of the Estimate & 4.00 \\
\hline Source: Results of Data Processing Using SPSS 17.0 &
\end{tabular}

The result of this test explains that all the independent variables (organizational readiness, external pressures, perceived ease of use, and perceived benefits that can be obtained from the use of ecommerce in SMEs creative industries) give the influence for about $48.3 \%$ to the e-commerce application in SMEs of Creative Industries in Jabodetabek area as shown in Table 8.

\section{Test F - ANOVA}

Table 9. ANOVA Test

\begin{tabular}{ccc}
\hline Test & F & Significant \\
\hline ANOVA & 16.32 & 0.00 \\
\hline
\end{tabular}

Source: Results of Data Processing Using SPSS 17.0 
The table shows that the F-value is 16.32 as shown in Table 9. This score is greater than 2.503 of Ftable with the significant value of 0.000 . Meanwhile, with the significant value of below 0.05 , it can be noted that all the independent variables (organizational readiness, external pressures, perceived ease of use, and perceived benefits that can be obtained from the use of e-commerce in SMEs creative industries) have affected the e-commerce application in SMEs creative industries in Jabodetabek area.

\section{$\mathrm{t}$ - Test}

From the table, it is found that t-score for variable of the organizational readiness is 2.531 with the significance value of 0.014 which is smaller than 0.05 . In addition, the $t$-score for perceived benefits variable is 4.92 with significance value of 0.000 which is also smaller than 0.05 . Meanwhile, it is also noted that both of the two variables have a value of t-score greater than 1.66 of t-table. In this case, it can be declared that the two variables have a significant influence on the e-commerce application.

On the other hand, the other two variables, namely epressure and the perceived ease of use, both variables do not have a significant effect on the adoption of the e-commerce. This conclusion is drawn based on the data on the table above.

As the data shows, the significance score for external pressure is 0.492 which means greater than 0.05 . Meanwhile, the t-score is 0.69 less than 1.66 of the t-table. In addition, the significance score for perceived ease of use is 0.476 and the t-score which is 0.71 is also less than 1.66 of the ttable.

\section{Result and Analysis}

From 4 independent variables (organizational readiness, external pressures, perceived ease of use and perceived of benefits that can be obtained from the use of e-commerce in SMEs creative industries) and one dependant variable (e-commerce adoption).

Table 10. Hypothesis Standardized Coefficient Result

\begin{tabular}{clcccc}
\hline Hypothesis & \multicolumn{1}{c}{ Description } & Beta & t & Sig & Result \\
\hline H1 & $\begin{array}{l}\text { Organizational Readiness significantly influence } \\
\text { E-commerce adoption. }\end{array}$ & 0.25 & 2.53 & 0.01 & Accepted \\
H2 & $\begin{array}{l}\text { External pressure significantly influence E- } \\
\text { commerce adoption. }\end{array}$ & 0.07 & 0.69 & 0.49 & Rejected \\
H3 & $\begin{array}{l}\text { Perceived ease of use (complexity) significantly } \\
\text { influence E-commerce adoption. }\end{array}$ & 0.06 & 0.71 & 0.47 & Rejected \\
H4 & $\begin{array}{l}\text { Perceived benefits significantly influence E- } \\
\text { commerce adoption }\end{array}$ & 0.49 & 4.92 & 0.00 & Accepted \\
\hline
\end{tabular}

Source: Results from Data Processing Using SPSS 17.0

As we can see in Table 10, the result of research inferred that organizational readiness $(\mathrm{H} 1)$ and perceived benefits ( $\mathrm{H} 4)$ have significantly influence e-commerce adoption. Meanwhile, external pressure (H2) and perceived ease of use (H3) have no significantly influence e-commerce adoption. Based on the result above, the regression model can be obtained is:

Remarks:

$$
\mathrm{Y}=-6.772+0.252 \times 1+0.495 \times 2+e
$$

$\mathrm{Y}=$ E-commerce adoption

$\mathrm{a}=$ Constanta 
$\mathrm{b}=$ Coefficient of Regression which shows the value of influences of independent variables to the dependent variable

$\mathrm{x} 1=$ Organizational readiness

$\mathrm{x} 2=$ Perceived benefits

$e=$ Error

From the above Regression Model, it can be noticed the following matters:

a. Any increase in the value of organizational readiness will raise the level of e-commerce adoption by 0.252

b. Any increase in the value of perceived benefits that can be obtained from the use of e-commerce in SMEs creative industries will increase the adoption of e-commerce as much as 0.495 .

From the equation of the regression model above, it can be inferred that if both the variables of the organizational readiness and the perceived benefit do not exist in the organization, then the value of e-commerce application will be -6.772. In that case, in order to achieve the purpose of the use of e-commerce in SMEs in the field of creative industries, both the variables of organization readiness and perceived benefits need to be improved.

\section{Discussion}

As mentioned above, the organizational readiness significantly influences the organization in the adoption of e-commerce. Hence, the SMEs of creative industries need to prepare their internal abilities. Alam et al. (2011) and Hong and Zhu (2006) revealed that the preparation in terms of technology has a significant influence to the organization readiness. The preparation refers to the availability of internet networks in SMEs, the skills in using internet, and knowledge about ecommerce possessed by managers as well as employees. These are also described in Hong and Zhu (2006) that the ability in applying this technology is important for SMEs, especially those who just started using e-commerce.

From the data analysis on respondents, it is found that there is still a lack of budget allocation issued by the respondent to develop the technology in term of applying e-commerce they do. As studied by Walczuch et al. (2000), Dennis (2000), MacGregor et al. (1998), Poon and Swatman (1997), and Abell and Limn (1996) in Macgregor and Vrazalic (2004), this phenomenon reflects how reluctant the SMEs are to spend money on technology and information.

Related to the perception on the benefit of e-commerce, it is believed that this perception will become the driving force for the SMEs to apply the e-commerce. Roger (2003) believes that the relative advantages of the use of e-commerce will make the SMEs managers to prioritize the use of e-commerce. In other words, the understanding of the benefits to be gained by the organization will attract SMEs to start using e-commerce. In line with previous research conducted by Wilson (2008), it is also believed that the understanding and knowledge about the multi benefits of e-commerce is more important than understanding the technology itself.

In term of the perception of the ease of e-commerce use, it is found that the ease of ecommerce use has no significant affect to the adoption of e-commerce in SMEs Creative Industries. Several studies by Eid et al. (2002), Kendall and Kendall (2001), Tambini (1999), Hadjimanolis (1999) mention that e-commerce can not be applied in some SMEs products (i.e manufacturing SMEs). This becomes one of the obstacles in applying the e-commerce.

Based on the studies by Alam et al. (2011), it is revealed that most SMEs in developing countries are reluctant to apply e-commerce in their business operations. This is because most of them consider applying e-commerce to be more complex or complicated because new technologies are used. The condition will discourage those SMEs to use e-commerce. Another reason is the lack of use and understanding technology in those SMEs creative industries. As mentioned in the "Book 
of Indonesian Creative Economy Development Planning of 2009" ("Buku Perencanaan Pengembangan Ekonomi Kreatif Indonesia 2009') issued by Ministry of Trade of Indonesia, most of the SMEs creative industries do not come from the IT-based industries. Most of them do not apply the high-tech. In other words, most of them have problems in applying the e-commerce or other technologies because of their lack of knowledge and ability in e-commerce technology.

Another study by Husnayati et al. (2008) also finds similar results in which the ease of using e-commerce does not impact the application of e-commerce significantly. Furthermore, it is revealed from this study that if the organization is used to apply the variety of computer systems in their work, then it will be familiar to apply e-commerce. In other words, by using e-commerce, it will make the organization will be more adapted and easier to apply the other computer applications. In the end, SMEs will be able to use a variety of new technology because they are used to these technologies.

From another study, Hong and Zhu (2006) added that the difficulty or ease of using technology is not significant in the application of e-commerce because of the involvement of a third party or outsourcing to manage and work on it. Some SMEs creative industries employed third party when they started using e-commerce. The goal is to help them because they still have a lack of understanding in basic and technical issues of e-commerce. Using third party in terms of ecommerce is applied by some of the respondents in the initial or start-up phase to the maintenance and training period.

In term of external pressure, as already mentioned, there are no significant effects from the pressure to apply e-commerce in SMEs Creative Industries. This is due to the tendency of the organizations not to focus on the consumers, but on the product. Consumers in this matter are considered as one of the SMEs' most important external factors. MacGregor \& Vrazalic (2004) claimed that it has been a character of the SMEs not to focus on the consumers. In other words, the SMEs creative industries pay a little attention on their external environment. This makes the external pressure insignificant effect to the use of e-commerce, Westhead \& Storey (1996) and Hill \& Stewart (2000).

Studies conducted by Abdurrohman (2011) also found that consumer readiness to start doing transactions through e-commerce, especially in Indonesia, are still low. One reason is the lack of confidence and trust of consumers to conduct transactions through e-commerce. A similar claim has also been stated by the Ministry of trade of the Republic of Indonesia in "The Book of Updating Indonesian Creative Industries in 2009" ("Buku Pemuktahiran Industri Kreatif Indonesia 2009" ) in which the Indonesian consumers are used to see directly with their own eyes when transactions take place. Obviously, this cannot happen if the transactions are done through e-commerce. However, lack of readiness of consumers to transact through e-commerce occurs not only in developing countries. From the studies conducted by Scupola (2009), it is found that the readiness of consumers has also been one of the obstacles to the use of e-commerce in Australia. In addition, another reason why there is no significant effect of the external pressure on the use of e-commerce is that the SMEs Creative Industries tend not to expand outside their own community

\section{Conclusion}

This study reveals that the application or adoption of e-commerce by the SMEs creative industry, especially in Jabodetabek, Indonesia, is significantly influenced by two independent variables, namely the organizational readiness and perceived benefit.

1. The variable of organizational readiness of the SMEs creative industries gives significant influence on the adaption of e-commerce. The organizational readiness has become one of several factors that significantly influence the adoption of e-commerce in SMEs creative industries in Jabodetabek. From the descriptive analysis as mentioned above, it is found that the availability of the internet, orientation for long-term business, the managers and employees' ability in using the computer have an important role in the readiness of SMEs to use ecommerce. 
2. External pressure variable does not influence significantly adoption of e-commerce. It is occured because the Indonesian consumers tend not to conduct business transactions through ecommerce. Besides, consumers do not seem give significant effect for the SMEs creative industries to eagerly use e-commerce. In other words, most Indonesian customers are not ready and motivated to use e-commerce yet. Indonesian customers prefer doing transactions in a traditional manner compared to the online way. Furthermore, Indonesian customers have a lack of confidence regarding online transaction due to many fraud cases related to e-commerce in society.

3. The variable of perceived ease of use of e-commerce does not have any significant effect to the application of e-commerce. In detail, due to the technical problems in using e-commerce, SMEs creative industries can still cooperate with a third party in terms of IT consulting and technology. Furthermore, from the questionnaire respond, it is found that "time consuming" became a main reason for SMEs respondents to be unable to understand technology innovation in e-commerce technology. That is the reason why variable of perceived ease of use is not significantly influence to e-commerce adoption.

4. Perceived benefits of e-commerce have the biggest effect on the application of e-commerce by SMEs Creative Industries in Jabodetabek. Based on the descriptive analysis described earlier, it is noted that the respondents tend to use e-commerce to be able to search for product information, compete with competitors better, become more competitive, save more money, and establish stronger relationship with business partners. In a nutshell, all these benefits encourage SMEs managers and owners to prioritize the use of e-commerce in their business. Finally, based on this understanding, the managers of SMEs creative industries seem to be more capable to face rising problems when using e-commerce.

\section{Managerial Implications}

The effect of both variables of external pressure and perceived ease of use of technology in this case is not supported by related data. The need of awareness in terms of external pressure is considered to be important. In other words, the lack of supervision by the organization to their surrounding environment should be avoided. Improving this supervision will raise their ability and competitive skills in business. Furthermore, looking around and paying more attention on the environment will make the business more flexible and dynamic for gaining the opportunities and coping with the coming threats.

In the mean time, in terms of perceived ease of using e-commerce, as stated by MacGregor and Vrazalic (2004), training and counseling to improve the ability to use the e-commerce are needed. In addition, they also add that the low ability and infrequently training conducted in the field of technology rouse other problems for the SMEs in their effort to apply the e-commerce. However, by employing a third party to develop e-commerce can be one solution to start using ecommerce.

In terms of the organization readiness, it is very important to pay more attention, especially in budget allocation for having more improvements which are closely related to the ability and the ease to use the e-commerce. The respondents' response for organizational readiness indicate that the organization tends to allocate very low or insufficient fund for the e-commerce application. In addition, it has also complaints from some respondents which often have faced technical problems in using the internet.

On the other side, in term of the variable of the benefit of e-commerce, it can be noted that most of the SMEs creative industries do not fully use e-commerce in searching for information for business benefit. In other words, the organizations do not use internet or e-commerce maximally to build extensive communication with suppliers or business partners. It is important to consider that the use of e-commerce has very important role in international trade and in terms of production and distribution activities. Having few number of activities in international trade does not have anything 
to do with the lack of fund allocation for the development of e-commerce as already discussed in the previous argument. In fact, it is believed that the need for the development of e-commerce will support the process, especially in terms of the method of payment, if SMEs join in the international market.

The existence of e-commerce can be used as a tool to support the production and distribution activities of a business. By applying e-commerce, the exchange of information related to business activities, such as the information on the production, the needs of the equipment, as well as the distribution of intangible products, will become more widespread.

\section{Recommendations}

Recommendation in this research are addressed for all managements of SMEs creative industries and institutions, such as the Ministry of Trade, the Ministry of Tourism and Creative Economy, the Ministry of Cooperatives, Small, and Medium Enterprises of Indonesia. All these institutions are expected to give their full support and motivation for the sake of the continued progress of the SMEs creative industries. Furthermore, they are also suggested to pay more attention on how the SMEs creative industries can gain more understanding of the importance of e-commerce. Also, these institutions are encouraged to provide more training for the SMEs creative industries to adopt the use of e-commerce. Hopefully, if the government can give their full attention and support, many SMEs creative industries will begin to use e-commerce in their business practices.

The conduct of training and the support in technical skills to utilize e-commerce by SMEs creative industries could be one way to improve the understanding and application of e-commerce. Training and motivation as well as the supply of information about the benefits of e-commerce need to be provided so that the SMEs creative industries will realize with the advantages of using ecommerce in their business practices. Furthermore, the support of IT infrastructure such as rapid internet access and the ability to get internet access anytime are also important. The government is hopefully able to synergize their work with PT. Telkom (State Owned Telecommunication Enterprise).

The authors also suggest that the government financially support any tools related to the development infrastructure and other aspects to raise the application of e-commerce by the SMEs creative industries. The financial support can be allocated for the SMEs creative industries to develop the e-commerce itself, especially in conducting the international trade which seems to be very low in quantity because of the inability to use e-commerce. As we know, in international trade, payment and other transaction are phases of business, and those need e-commerce method.

For all managers of SMEs creative industries, they should continue their struggle to improve and make more creations to develop their businesses. Again, the use of e-commerce with its various benefits as discussed earlier seems to be the right choice for all the SMEs creative industries to enhance their businesses. It is believed that the proportion of funds, man power and attention allocated by the SMEs creative industries will provide superior results when the SMEs creative industries fully apply e-commerce. Furthermore, the allocation of funds for development is expected to bring the benefits of the use of e-commerce. Proper development in payment facilities for international markets would be expected to be the initial step of SMEs creative industries to go internationally. The potential magnitude of international market, the existence of this SMEs creative industry can also raise the knowledge of Indonesias' as one of the countries with the largest number of SMEs creative industries, similar to European countries.

\section{Future research}

It is recommended that future research should take consideration of other determinants towards the adoption of e-commerce among SMEs creative industries in Jabodetabek, Indonesia. The availability of other determinants will make sure that the accuracy of measurements are more significant. 
Moreover, further research should measure the adoption of e-commerce based on each SMEs of creative industry. Because each creative industry has its uniqueness, so measurement based on each industry will give more generalizability of study.

\section{References}

Abdurrohman. (2011). Analisis faktor-faktor yang Mempengaruhi Adopsi E-commerce (Multi Studi kasus: UMKM di Wilayah Depok dan Sekitarnya). Jakarta: Economics Faculty Universitas Indonesia.

Abell, W., \& Lim, L. (1996). Business use of the internet in New Zealand: an explatory study, retrieved from http://ausweb.scu.edu.au/aw96/business/abell/paper.htm at July 2012.

Alam, S.S., Omar, N.A., Hisbam, Nik, M.H.N.H. (2011). Applying the theory of perceived charateristic of innovating (PCI) on ICT adoption in the smes in malaysia. Australian Journal of Basic and Applied Sciences, 5 (8), 8-17.

Beatty, R.C., Shim J.P., Jones M.C. (2001). Factors influencing corporate web site adoption: a time based assessment. Information \& Management Journal, 38 (6), 337-354.

BPS-Central Agency of Statistics. (2010). Klasisifikasi umkm (data in Indonesian language). Retrieved from http://www.bps.go.id at November 2012.

Chen, J., \& McQueen, R. (2008). Factors affecting e-commerce stages of growth in small chienese firm in new zealand: an analysis of adoption motivators and inhibitors. Journal of Global Information Management, 16 (1), 26-60.

Chong, A.Y.L., Lin, B., Ooi, K.B \& Raman, M. (2009). Factors affecting the adoption level of ecommerce: an empirical study. Journal Computer Information System, (50), 13-22.

Cooper D. R., \& Schindler, P.S. (2006). Business Research Methods. New York: McGraw Hill.

Data UMKM 2006-2010 Ministry of cooperative small \& medium enterprises of indonesia. (article in indonesian languange). Retrieved from http://www.depkop.go.id/ at September 2012.

Dennis, C. (2000). Networking for marketing decision. Management Decision, 38 (4), 287-292.

Dholakia, R.R., Palvia, R., \& Krishnan, B. (2004). Factors impacting the adoption of web-enabled transaction processing by small business. Journal of Small Business Economy, (23), 311322.

Eid, R., Trueman, M., \& Ahmed, A.M. (2002). A cross industry review of b2b critical sucess factors, Internet Research: Electronic Networking Application and Policy, 12 (2), 110-123.

Grandon, E.E., \& Pearson J.M. (2004). Electronic commerce adoption: an empirical study of small and medium US businesses. Information \& Management Journal, 42 (1), 197-216.

Hadjimanolis, A. (1999). Barriers to innovation for SMEs in a small less developed country (cyprus), Technovation, 19 (9), 561-570.

Hill, R., \& Stewart, J. (2000). Human resource development in small organisations. Journal of European Industrial Training, 24 (2/3/4), 105-117.

Hong, W., \& Zhu, K. (2006). Migrating to internet-based e-commerce: factor Affecting e-commerce adoption and migration at the firm level. Journal Information \& Management 43 (2), 204221. 
Husnayati, H., Rafidah, M.N., \& Mohd, A.S. (2008). Perceived attributes of e-commerce and the adoption decision: the case of Malaysian SMEs. Jurnal Teknologi Maklumat \& Multimedia, 5 (2008), 107-125.

Hussey, J., \& Hussey, R.(1997). Business Research: A Practical Guide for Undergraduate and Postgraduate Students. Great Britain: Mc Millan Press Ltd.

Jacobs, G.,\& Dowsland, W. (2000). The dot-com economy in wales: the long road ahead. UK Academy of Information Systems Conference, Swansea, 65: 590-596.

Kalakota, R., \& Whinston, A.B. (1997). Electronic Commerce-A Manager's Guide. Massachusetts: Addison-Wesley Longman.

Kendall, J.E., \& Kendall, K.E. (2001). A paradoxically peaceful coexistence between commerce and e-commerce, Journal of Information Technology, Theory and Application, 3 (4), 1-6.

Kontan.co.id. (2012). E commerce di Indonesia potensi kantongi Rp $330 \mathrm{~T}$ (article in Indonesian language). Retrieved from http://industri.kontan.co.id/news/e-commerce-di-indonesiapotensi-kantongi-rp-330-t at 21 July 2012.

Kuan, K.K.Y., \& Chau, P.Y.K. (2001). A Perception-based model for EDI adoption in small businesses using a technology-organization-enviroment framework. Information \& Management Journal, 38 (8), 507-521.

Lawson, R., Alcock, C., Cooper, J., \& Burges, L. (2003). Factor affecting adoption of electronic technologies by SMEs: an australian study. Journal of Small Business and Enterprise Development, 10 (3), 265-276.

MacGregor, R.C., Bunker, D.J., \& Waugh, P. (1998). Proceedings of the 11th International Bled Electronic Commerce Conference: Electronic commerce and small/medium enterprises (SMES) in Australia: an electronic data interchange (EDI). Pilot study, Slovenia.

MacGregor, R.C., \& Vrazalic, L. (2004). Electronic commerce adoption in small to medium enterprise: a comparative study of smes in Wollongong (Australia) and Karlstad (Sweden). School of Economic and Information Systems. University of Wollongong.

Mehrtens J., Cragg P.B., Mills A.M. (2001). A model on internet adoption by smes. Information \& Management Journal, 39 (3), 165-176.

Ministry of Trade of Indonesia. (2009). Buku Pemuktahiran Industri Kreatif Indonesia 2009 (article in Indonesian language) Jakarta.

Ministry of Cooperative and Small Medium Enterprise. (2012). Data ukm 2006-2010 kementerian koperasi dan usaha kecil dan menengah. Retrieved from http://www.depkop.go.id/phocadownload/data\%20usaha\%20mikro\%20kecil\%20menenga h\%20umkm\%20dan\%20usaha\%20besar\%20ub\%20tahun\%202006-2010.pdf at September 2012.

Poon, S., \& Swatman, P. (1997). The internet for small business: an enabling infrastructure. The 5th Internet Society Conference, 221-231.

Rogers, E.M. (2003). Diffusion of Innovations, 5th edition. New York: Free Press.

Scupola, A. (2009). SME's e-Commerce Adoption: perspective from denmark and australia. Journal of Enterprise Information Management, Vol. 22 No 2009.

Shaharudin, M.Z., Omar, M.W., Elias, S.J., Ismail, M., Ali, S.M., Fadzil, M.I. (2012). Determinant of electronic commerce adoption in malaysian smes' furniture industry. African Journal of Business Management, 6 (10), 3648-3661. 
Tambini, A.M. (1999). E-shopper demand e-service, Discount Store News, 11 (38).

Waizly, D. (2012, March 28). Top 50 ukm di dunia online. Marketeers. (article in Indonesian language). Retrieved from .http://the-marketeers.com/archives/majalah-marketeers-top-50ukm-di-dunia-online.html at December 2012.

Walczuch, R., Braven, G.V., \& Lundgren, H. (2000). Internet adoption barriers for small firms in the netherlands. European Management Journal, 18 (5), 561-672.

Westhead, P., \& Storey, D.J. (1996). Management training and small firm performance: why is the link so weak?. International Small Business Journal, 14 (4), 13-24.

Wilson, H., Daniel, E. \& Davies, I.A. (2008). The diffusion of e-commerce in uk smes. Journal of Marketing Management. 24 (5-6), 489-516. 